\title{
Synthesis, Characterization and Antidiabetic Evaluation of Sulfonamide in Corporated with 1,3,4-0xadiazole Derivatives
}

\author{
Megha Tukaram Salve*, Shailaja Bhanudas Jadhav Sr \\ Department of Pharmaceutical Chemistry of Modern College of Pharmacy, Nigdi, Pune, Maharashtra, INDIA.
}

\begin{abstract}
Aim/Background: There is an increasing prevalence of diabetes mellitus throughout the world, and new compounds are necessary to combat this. While the current available antidiabetic therapies are long-term complicated and side effects-prone, this has led to a demand for more affordable, more effective methods of tackling diabetes. Research is focused on finding alternative medicinal remedies with significant antidiabetic efficacy as well as low adverse effects. This study synthesized, characterized, and evaluated anti-diabetic properties of synthetic sulphonamide hybrid of 1,3,4-oxadiazole derivatives. Materials and Methods: An in vivo antihyperglycemic evaluation of the sulphonamide hybrid of 1,3,4-oxadiazole derivatives was conducted using wistar rat models of type II diabetes derived from a two-step synthesis. Our study examined the effects of synthesized compounds on a model induced by a high-fat diet combined with streptozotocin and nicotinamide injection. For assessment of diabetic effects, Vildagliptin $(10 \mathrm{mg} / \mathrm{kg} / \mathrm{day})$ was used as the standard drug. On day $14^{\text {th }}, 1,3,4$-oxadiazole derivatives ( $50 \mathrm{mg} / \mathrm{kg} / \mathrm{day}$ ) significantly lowered the blood sugar of hyperglycemic rats. Results: Due HFD STZ with Nicotinamide blood glucose level of wistar rat was increased $(295 \pm 8.2)$. After $14^{\text {th }}$ day administration of derivatives random blood glucose level under controlled. A-III $(220 \pm 7.5 \mathrm{~B})$ and A-IV $(222 \pm 3.62 \mathrm{~B})$ were lowered random blood glucose levels on wistar rat. As compared to diabetes control (295 \pm 8.5$)$, derivatives of 1,3,4-oxadiazole are considered promising lead compounds. Compounds A-III and A-IV were found to be the most effective in lowering blood glucose, indicating the potential of these compounds as antidiabetic agents. Conclusion: Hybrids developed in this study provide new classes of anti-diabetic agents, and further optimization can be performed using this information.
\end{abstract}

Key words: In vivo study, 1,3,4-Oxadiazole, Sulfonamide derivative, anti-diabetic agents.

\section{INTRODUCTION}

Hyperglycemia caused by defects in insulin secretion, insulin action, or both, is recognized as a diabetic condition. ${ }^{1} \mathrm{~A}$ diabetic condition (DM) is a chronic disease characterized by hyperglycemia and is categorized into types 1 and 2 which may differ from each other in pathogenesis. ${ }^{2}$ A diabetic condition is defined as high blood sugar levels (above $130 \mathrm{mg} / \mathrm{dl}$ ) that cause longterm damage, dysfunction, and even failure to various body systems including the eyes, kidneys, nerves, heart, and vessels that carry blood. $^{3}$
Several compounds containing heterocyclic rings are important components of antidiabetic pharmaceutical products. Nitrogen, sulfur, and oxygen containing heterocyclic compounds have attracted the attention of medicines chemical due to their wide range of biological applications. Among the heterocyclic family, 1,3,4-oxadiazole derivatives have shown many promising applications in pharmaceuticals. ${ }^{4,5}$ Blood glucose stimulates the release of insulin from beta cells. ${ }^{3}$ In addition to insulin deficiency and insulin resistance, there is also a genetic defect in the cells of the $\beta$ axis of the
Submission Date: 24-05-2021; Revision Date: 29-07-2021; Accepted Date: 01-11-2021

DOI: 10.5530/ijper.55.4.214 Correspondence:

Mrs. Megha Tukaram Salve Jr,

Department of Pharmaceutical Chemistry of Modern College of Pharmacy, Nigdi, Pune-411044, Maharashtra, INDIA.

Phone: 91-0241-2328977, Email-meghasalve77@ gmail.com

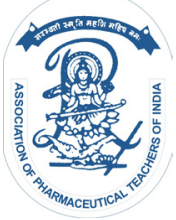

www.ijper.org 
pancreas that contributes to diabetes. This disorder is also a result of obesity, aging, and lack of exercise. Sulfonamide and oxadiazole are two potential anti-diabetic drug candidates. A potential antidiabetic drug candidate contains the sulfonamide group and the oxadiazole ring. A sulfonamide group capable of electron-withdrawal is found within the ligand, while oxadiazole rings are the pharmacophores with antidiabetic activity.

WHO reports that diabetes complications account for 2.2 million deaths and diabetes itself is responsible for 1.5 million deaths. ${ }^{6,7}$ In low-income, as well as middleincome countries, there are a greater number of deaths. The result of uncontrolled diabetes is hyperglycemia, which causes glycosylation of blood proteins, which results in comorbidities such as neuropathy, retinopathy, cardiomyopathy, and heart attack. Diabetes is treated with several drugs, among which sulfonylureas are the most common due to their economical and safe nature. The drugs stimulate calcium accumulation and insulin secretion, stopping the potassium transfer protein from performing its function. Novel heterocyclic sulphonamide-oxadiazole hybrid compounds are being tested against diabetes, to develop safer, more potent and relatively low-cost hyperglycemic agents. Tolbutamide has been commercialized since 1950 when it was introduced in the marketplace and is especially useful for patients with T2D with existing $\beta$ cells that are not yet releasing insulin. Sulfonylureas have been used for at least twenty years, beginning with Tolbutamide introduced as chlorpropamide, glycopyramide, tolazamide, acetohexamide, and glibenclamide for the treatment of T2D. ${ }^{8-10}$
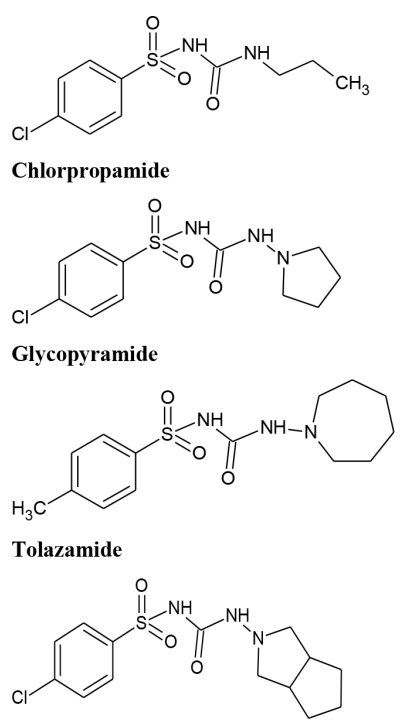

Gliclazide
This study reports the synthesis of various sulfonamide hybrids and their in vivo studies as anti-diabetic agents using Wistar rats. As a standard drug, Vildagliptin was used as well as carboxymethyl cellulose (CMC) to control diabetes. Blood glucose levels were reduced by some compounds.

\section{MATERIALS AND METHODS}

All the reagents and chemicals employed were of analytical grade and were not purified further. The chemicals were purchased from Merck Life Science and Research Lab Fine Chem Industry. Characterization of intermediates and final compounds was carried out utilizing several physicochemical and spectral techniques. Melting points of the compounds were determined on open capillaries on Labronics LT-115 digital. FT-IR spectra were captured by using a Bruker FT-IR.14 The NMR spectra of the synthesized compounds were recorded on $\mathrm{CDCl} 3$ (unless specified) with TMS as an internal reference (chemical deviation in $\delta$, ppm) using the 100183-SND $400 \mathrm{MHz}$ instruments and the 100186-SND $400 \mathrm{MHz}$ instruments.15 IR spectra were obtained from the Bruker spectrometer. Elemental analysis of the compounds was carried out by SAIF IIT BOMBAY. The physicochemical, analytical and spectral characterization data for the final compounds (A-I - A-VI) were provided in Table 1 and Table: 2 respectively.

\section{Experimental Chemistry}

Title compounds A-I - A-VI have been synthesized in accordance with Scheme 1. Substituted benzaldehyde $(0.5 \mathrm{mmol})$ in $1 \mathrm{ml}$ methanol was mixed with semicarbazid hydrochloride $(0.5 \mathrm{mmol})$ and sodium acetate $(0.5 \mathrm{mmol})$ in water $10 \mathrm{~min}$ at RT. Under reduced pressure, the insolvent evaporated after stirring for $10 \mathrm{~min}$. The resulting residue was redissolved in 1,4-dioxane $(5 \mathrm{ml})$ followed by the addition of potassium carbonate $(1.5 \mathrm{mmol})$ and iodine $(0.6 \mathrm{mmol})$ add sequentially stirred for $1-4.5 \mathrm{hr}$ at $80^{\circ} \mathrm{C}$. Reaction was monitored by TLC with solvent acetone and benzene $(9: 1)$. Led to the formation of the next in-between compound 5-Substituted 2-amino-1,3,4-oxadiazole. ${ }^{12}$

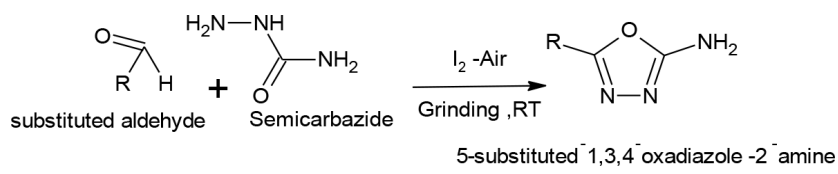

Reaction of compound 5-Substituted 2-amino-1,3,4oxadiazole $(2 \mathrm{mmol})$ with 2-cyanopyrrolidine-1-sulfonyl chloride $(1 \mathrm{mmol})$ in the presence of ethanol $(2 \mathrm{ml})$ were continuously stirring at room temperature resulted 
Table 1: Physico-chemical characterization data for final compounds A-I to A-VI.

\begin{tabular}{|c|c|c|c|c|c|c|}
\hline Sr.no & Compound code & $\mathbf{R}$ & Molecular Formula & Molecular Weight & M. P. $\left({ }^{\circ} \mathbf{C}\right)$ & \% Yield \\
\hline 1 & A-I & 4-Cl Phenyl & $\mathrm{C}_{13} \mathrm{H}_{12} \mathrm{CIN}_{5} \mathrm{O}_{3} \mathrm{~S}$ & 353.784 & $262-264$ & 75 \\
\hline 2 & A-II & 3-Cl Phenyl & $\mathrm{C}_{13} \mathrm{H}_{12} \mathrm{CIN}_{5} \mathrm{O}_{3} \mathrm{~S}$ & 353.784 & $252-254$ & 72 \\
\hline 3 & A-III & 3-NO2 Phenyl & $\mathrm{C}_{13} \mathrm{H}_{12} \mathrm{~N}_{6} \mathrm{O}_{5} \mathrm{~S}$ & 364.337 & $252-255$ & 76 \\
\hline 4 & A-IV & 2-Cl Phenyl & $\mathrm{C}_{13} \mathrm{H}_{12} \mathrm{CIN}_{5} \mathrm{O}_{3} \mathrm{~S}$ & 353.784 & $212-215$ & 71 \\
\hline 5 & A-V & 4-NH(CH3) Phenyl & $\mathrm{C}_{15} \mathrm{H}_{18} \mathrm{~N}_{6} \mathrm{O}_{3} \mathrm{~S}$ & 362.407 & $248-250$ & 70 \\
\hline 6 & A-VI & 4- $\mathrm{NH}(\mathrm{CH} 3)$ Phenyl & $\mathrm{C}_{13} \mathrm{H}_{12} \mathrm{~N}_{6} \mathrm{O}_{5} \mathrm{~S}$ & 364.337 & $252-255$ & 69 \\
\hline
\end{tabular}

\begin{tabular}{|c|c|c|c|c|c|c|}
\hline \multirow[t]{2}{*}{ Code } & \multirow[t]{2}{*}{ IR (KBr, cm-1) } & \multirow{2}{*}{$\begin{array}{c}{ }^{1} \mathrm{H} \text { NMR } \\
\left(\mathrm{CDCl}_{3}, \delta \text { in ppm) }\right.\end{array}$} & \multirow{2}{*}{$\begin{array}{c}{ }^{13} \mathrm{C} \text { NMR } \\
\left(\mathrm{CDCl}_{3}, \delta \text { in ppm }\right)\end{array}$} & \multirow{2}{*}{$\begin{array}{c}\text { Mass } \\
(\mathrm{m} / \mathrm{e}) \\
{[\mathrm{M}+\mathrm{H}]^{+}}\end{array}$} & \multicolumn{2}{|c|}{ Elemental analysis } \\
\hline & & & & & $\begin{array}{c}\text { Calculated } \\
\text { Observed }\end{array}$ & $\begin{array}{l}\text { Calculated } \\
\text { Observed }\end{array}$ \\
\hline A-I & $\begin{array}{c}3300(\mathrm{~N}-\mathrm{H} \text { stretch }), \\
3000(=\mathrm{C}-\mathrm{H} \text { stretch), } \\
2200(-\mathrm{C} \equiv \mathrm{N} \text { str. }), 1600((\mathrm{C}- \\
\mathrm{H} \text { bend.), } 1450(\mathrm{CH} 2 \text { bend. }), \\
1400(\mathrm{~S}=\mathrm{O} \text { asym sulfonamide) } \\
1200(\mathrm{~S}=\mathrm{O} \text { sym sulfonamide }) \\
, 600(\mathrm{C}-\mathrm{Cl})\end{array}$ & $\begin{array}{c}\text { 10.5(s,1H), 7.2(d,2H), } \\
7.53(\mathrm{~d}, 2 \mathrm{H}), 3.8(\mathrm{~s}, 1 \mathrm{H}) \\
1.2-2.4(\mathrm{~m}, 6 \mathrm{H})\end{array}$ & $\begin{array}{c}\text { 169.3,166.7, 148.7 } \\
\text { 145-130, 78, 56-45, } \\
30-20\end{array}$ & 354.04 & $\begin{array}{c}\mathrm{C}(44.13 \%), \\
\mathrm{H}(3.42 \%), \\
\mathrm{N}(19.8 \%)\end{array}$ & $\begin{array}{l}\mathrm{C}(44.10 \%), \\
\mathrm{H}(3.40 \%), \\
\mathrm{N}(19.4 \%)\end{array}$ \\
\hline A-II & $\begin{array}{c}3300(\mathrm{~N}-\mathrm{H} \text { stretch }), \\
3050(=\mathrm{C}-\mathrm{H} \text { stretch }), \\
2200(-\mathrm{C} \equiv \mathrm{N} \text { str. }) \\
1600((\mathrm{C}-\mathrm{H} \text { bend. }), 1560 \\
(\mathrm{S}=\mathrm{O} \text { asym sulfonamide }), \\
1455(\mathrm{~S}=\mathrm{O} \text { asym sulfonamide }), \\
780(\mathrm{C}-\mathrm{Cl})\end{array}$ & $\begin{array}{c}\text { 10.5(s,1H), 8.15(s,1H), } \\
8.10(\mathrm{~d}, 1 \mathrm{H}) \\
7.6(\mathrm{~m}, 2 \mathrm{H}), 3.8(\mathrm{~s}, 1 \mathrm{H}) \\
1.64-2.8(\mathrm{~m}, 6 \mathrm{H})\end{array}$ & \begin{tabular}{|c|}
$169.3,164.5$ \\
$134.8-125.6,116.2$ \\
$56-45.6$ \\
$29.3-20.9$
\end{tabular} & 354.04 & $\begin{array}{l}\mathrm{C}(44.13 \%), \\
\mathrm{H}(3.42 \%) \\
\mathrm{N}(19.8 \%)\end{array}$ & $\begin{array}{c}\mathrm{C} \\
(44.10 \%), \\
\mathrm{H}(3.40 \%), \\
\mathrm{N}(19.2 \%)\end{array}$ \\
\hline A-III & $\begin{array}{c}3490(\mathrm{~N}-\mathrm{H} \text { str. }), \\
3000(=\mathrm{C}-\mathrm{H}) \text { stretch, } \\
2240(-\mathrm{C} \equiv \mathrm{N} \text { str. }), \\
1600 \text { (C-H bend.), } \\
1500 \mathrm{~N}-\mathrm{O} \text { stretching } \\
\text { (asymmetrical), } \\
1460(\mathrm{CH} 2 \text { bend.), } 1400 \\
\text { ( }=\mathrm{O} \text { asym sulfonamide) } \\
1200 \text { (N-O stretching } \\
\text { (symmetrical), } \\
1150 \text { ( }=\mathrm{O} \text { sym sulfonamide) }\end{array}$ & $\begin{array}{c}10.58(\mathrm{~s}, 1 \mathrm{H}) 8.6(\mathrm{~d}, 2 \mathrm{H}), \\
7.8(\mathrm{~d}, 2 \mathrm{H}), 3.8(\mathrm{~s}, 1 \mathrm{H}), \\
1.64-2.8(\mathrm{~m}, 6 \mathrm{H})\end{array}$ & \begin{tabular}{|c|}
$169.3,164.5$ \\
$148.4,133.6-122.8$ \\
$116.2,55-45.6$ \\
$29.3-20.9$
\end{tabular} & 365.05 & $\begin{array}{l}\mathrm{C}(42.86 \%), \\
\mathrm{H}(3.32 \%), \\
\mathrm{N}(23.07 \%)\end{array}$ & $\begin{array}{c}\text { C } \\
(42.82 \%), \\
\mathrm{H}(3.30 \%), \\
\mathrm{N}(23.02 \%)\end{array}$ \\
\hline A-IV & $\begin{array}{c}3350(\mathrm{~N}-\mathrm{H} \text { stretch }), \\
3000(=\mathrm{C}-\mathrm{H} \text { stretch }), \\
2240(-\mathrm{C} \equiv \mathrm{N} \text { str. }), \\
1600(\mathrm{C}-\mathrm{H} \text { bend. }), \\
1450\left(\mathrm{CH}_{2} \text { bend. }\right) \\
1400(\mathrm{~S}=\mathrm{O} \text { asym sulfonamide }), \\
1200(\mathrm{~S}=\mathrm{O} \text { sym sulfonamide }), \\
800(\mathrm{C}-\mathrm{Cl})\end{array}$ & $\begin{array}{c}10.58(\mathrm{~s}, 1 \mathrm{H}), 7.61(\mathrm{~d}, 1 \mathrm{H}) \\
7.71(\mathrm{~d}, 1 \mathrm{H}), 7.38(\mathrm{t}, 2 \mathrm{H}) \\
3.8(\mathrm{~s}, 1 \mathrm{H}), 1.64-2.8(\mathrm{~m}, 6 \mathrm{H})\end{array}$ & $\begin{array}{c}169.3,164.5 \\
132.2-125,116.2 \\
55-45,29.3-20.9\end{array}$ & 354.04 & $\begin{array}{l}\mathrm{C}(44.13 \%), \\
\mathrm{H}(3.42 \%), \\
\mathrm{N}(19.8 \%)\end{array}$ & $\begin{array}{c}\mathrm{C} \\
(44.10 \%), \\
\mathrm{H}(3.40 \%), \\
\mathrm{N}(19.2 \%)\end{array}$ \\
\hline$A-V$ & $\begin{array}{c}\text { 3400(N-H str.), } 3000 \\
\text { (C-H str. aromatic), } \\
2900-3000 \\
\text { (C-H stretch methyl group), } \\
2250 \text { (-C } \equiv \mathrm{N} \text { str.), } 1650 \text { ( } \mathrm{C}-\mathrm{H} \text { bend.), } \\
1600 \text { ( } \mathrm{S}=\mathrm{O} \text { str sulfonyl group), } \\
1450 \text { (CH2 bend.) }\end{array}$ & $\begin{array}{c}\text { ס10.6(s,1H), 7.50(d,2H), } \\
\text { 6.87(d,1H), 3.80(s,1H), } \\
\text { 3.2(m,6H), 1.4-2.4(m,6H); }\end{array}$ & $\begin{array}{c}169.3,166.5, \\
143.66 \\
123.52-135.85, \\
60.0-50, \\
18.7-14.16\end{array}$ & 363.12 & $\begin{array}{l}\mathrm{C}(49.71 \%), \\
\mathrm{H}(5.01 \%), \\
\mathrm{N}(23.19 \%)\end{array}$ & $\begin{array}{c}\mathrm{C} \\
(49.65 \%), \\
\mathrm{H}(4.98 \%), \\
\mathrm{N}(23.10 \%)\end{array}$ \\
\hline $\mathrm{A}-\mathrm{VI}$ & $\begin{array}{c}3490(\mathrm{~N}-\mathrm{H} \text { stretch), } \\
3100(=\mathrm{C}-\mathrm{H} \text { stretch }), \\
2240(-\mathrm{C} \equiv \mathrm{N} \text { str. }), \\
1600(\mathrm{C}-\mathrm{H} \text { bend.), } 1500 \\
(\mathrm{N}-\mathrm{O} \text { stretching (asymmetrical), } \\
1460\left(\mathrm{CH}_{2} \text { bend.), } 1200\right. \\
\text { ( } \mathrm{N}-\mathrm{O} \text { stretching (symmetrical), } \\
1150 \text { ( } \mathrm{S}=\mathrm{O} \text { sym sulfonamide) }\end{array}$ & $\begin{array}{c}\text { 10.5(s,1H), 8.3(d,2H), } \\
8.8(\mathrm{~d}, 2 \mathrm{H}), 3.83(\mathrm{~s}, 1 \mathrm{H}), 1.2- \\
2.8(\mathrm{~m}, 6 \mathrm{H}),\end{array}$ & $\begin{array}{c}166.5,169.3,45.6 \\
55,147.9,132.2 \\
128.8,130.9 \\
128.8,130.9,116.2 \\
29.3,20.9\end{array}$ & 365.05 & $\begin{array}{l}\mathrm{C}(42.86 \%), \\
\mathrm{H}(3.32 \%), \\
\mathrm{N}(23.07 \%)\end{array}$ & $\begin{array}{c}\mathrm{C} \\
(42.82 \%), \\
\mathrm{H}(3.32 \%), \\
\mathrm{N}(23.02 \%)\end{array}$ \\
\hline
\end{tabular}


in the formation of the 2-cyano-N-(5-substituted -oxadiazol-3-yl)pyrrolidine-1-sulfonamide (A-I - A-VI). ${ }^{13}$
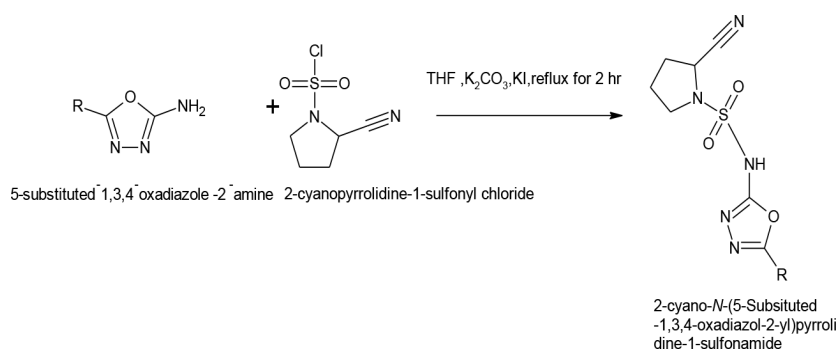

4-Cl Phenyl, 3-Cl Phenyl, 3-NO $\mathrm{N}_{2}$ Phenyl, 2-Cl Phenyl, 4-NH( $\left(\mathrm{CH}_{3}\right)$ Phenyl, 4-NO 2 Phenyl.

\section{Pharmacological Evaluation}

All experimental treatments were carried out in compliant with CPCSEA guidelines and licensed by IAEC's foundation (MCP/IAEP/010/2020).

\section{Animals}

Animal model 72 female Wistar rats age 8 weeks (80-120 gm ) were used in the antidiabetic Study. After 1 week of acclimatization, composition and preparation of the high-fat diet (HFD). After 8 weeks of HFD, rats were fasted overnight and animals became diabetic by a single intraperitoneal injection of STZ $(35 \mathrm{mg} / \mathrm{kg}$ body weight) and nicotinamide $(120 \mathrm{mg} / \mathrm{kg})$. As STZ is capable of producing fatal hypoglycemia as a result of massive insulin release, the rats were treated with a $5 \%$ glucose solution for $24 \mathrm{hrs}$.

\section{For evaluation of anti-diabetic activity}

The diabetic animals were divided into nine groups of eight animals each. All the synthesized compounds were administered orally (prepared in 1\% Sodium CMC). The random blood glucose levels were measured at the dose $1^{\text {st }}, 7^{\text {th }}, 14^{\text {th }}$, and $28^{\text {st }}$ days intervals after treatment of synthesized compound using the blood glucose test strips and the glucometer on blood samples collected via by a tail prick (Table 3). Vildagliptin have same biotargets as well as structural similarity of synthesized compounds so it used as standard drug.

\section{RESULTS AND DISCUSSION}

We have reported eco-friendly iodine-mediated oxidative intermolecular $\mathrm{C}-\mathrm{O} / \mathrm{C}-\mathrm{N}$ bond formation reaction for the preparation of 1,3,4-oxadiazoles. Substituted Benz aldehydes were converted into substituted 2-amino1,3,4-oxadiazole to good yield. Aromatic aldehydes were used to synthesized 1,3,4-oxadiazole target compounds. The structure of 5-(3-chlorophenyl)-1,3,4-oxadiazol2-amine was confirmed CHN study, IR, ${ }^{1} \mathrm{H}$ NMR. The peak at $3400-3300$ and $3330-3250 \mathrm{~cm}^{-1}$ in IR spectrum indicate the presence of primary amine that confirm the formation of 5-(3-chlorophenyl)-1,3,4-oxadiazol2-amine. The peak at $1760-1640 \mathrm{~cm}^{-1}$ in the IR spectrum indicates the $\mathrm{CHO}$ group of benzaldehyde was disappeared. ${ }^{1} \mathrm{H}$ NMR spectrum wherein a peek at $\delta 7.65$ for the $\mathrm{NH}_{2}$ proton of the primary amine appeared and was in a single peak at $\delta 9.89$ for the $-\mathrm{CHO}$ proton was disappeared. $[\mathrm{M}+\mathrm{H}]^{+}$Peak at 196.02 of 5-(3-chlorophenyl)-1,3,4-oxadiazol-2-amine was confirmed from its ESI-MS spectrum.

In the second step absence of any catalyst, the reaction was conducted in ethanol. Primary aromatic amines react with electron-withdrawing group sulphonyl chloride in presence of ethanol to get the product sulphonamide. Final compound was confirmed by characterization by CHN study, IR, ${ }^{1} \mathrm{H}$ NMR (Table 2). The peak at 3500$3350 \mathrm{~cm}-1$ in the IR spectrum indicates the presence of secondary amine $\mathrm{N}-\mathrm{H}$ stretching. ${ }^{1} \mathrm{H}$ NMR spectrum wherein a singlet peak at $\delta 10.5$ for secondary amine appeared and ${ }^{1} \mathrm{H}$ NMR spectrum wherein a peek at $\delta$ 7.65 for the $\mathrm{NH}_{2}$ proton of the primary amine was disappeared. The peak at $1200-1000 \mathrm{~cm}^{-1}$ and $1420-1300$

Table 3: Effect of tested compounds (50 $\mathbf{~ m g / k g / d a y ) ~ r e l a t i v e ~ t o ~ V i l d a g l i p t i n ~ ( 1 0 ~ m g / k g / d a y ) ~ o n ~ r a n d o m ~ b l o o d ~}$
glucose level in serum of rats.




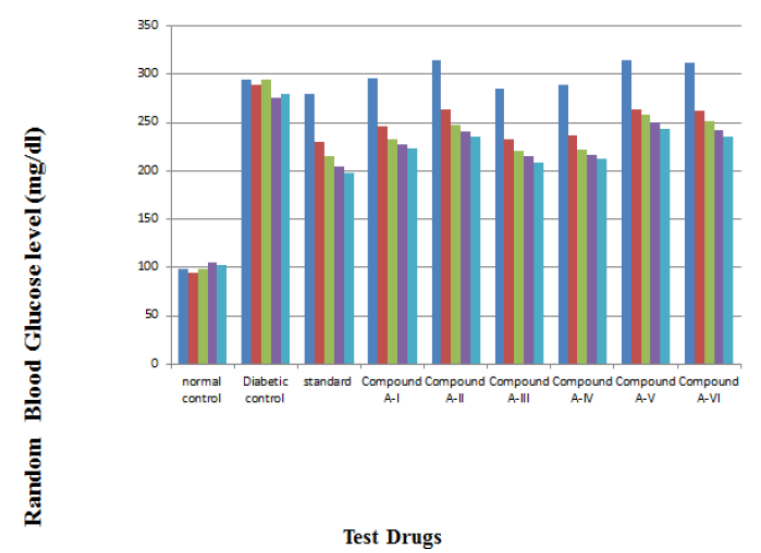

Figure 1: Effect of test compound $(50 \mathrm{mg} / \mathrm{kg})$ and Vildagliptin $(10 \mathrm{mg} / \mathrm{kg})$ on random blood glucose level in STZ-Nicotinamide induced diabetes rats.

$\mathrm{cm}^{-1}$ in the IR spectrum indicates the presence of the sulphonyl group. The peak at $\sim 2250 \mathrm{~cm}^{-1}$ in the IR spectrum indicates the presence of the nitrile group. From this characterization, A-II was confirmed. $[\mathrm{M}+\mathrm{H}]^{+}$peak at 354.04 of A-II was confirmed from its ESI-MS spectrum. The properties of the synthesized 1,3,4-oxadiazoles sulfonamides hybrids are summarized in Table 1. Anti-hyperglycemic activity of all the synthesized compounds (A-I to AVI) was carried out in HFD STZNicotinamide induced diabetic rats using Vildagliptin as a standard drug (Table 3). Sulfonamides hybrid compounds were evaluated with random blood glucose levels. At the dose of $50 \mathrm{mg} / \mathrm{kg} / \mathrm{day}$, the synthesized compounds showed excellent reductions in glucose levels in rats after $14^{\text {th }}$ days (Figure 1 ). Sulfonamide hybrid compounds (A-I -A-VI ) are more effective at reducing hyperglycemia in rats at $50(\mathrm{mg} / \mathrm{kg} /$ day) than a control rat administered only CMC.

\section{CONCLUSION}

Synthesized sulfonamides hybrids were characterized by FT-IR, 1H-NMR, C13 NMR spectroscopy and CHN analysis and evaluated for in vivo antidiabetic activity. In this study, 1,3,4-oxadiazoles sulfonamides hybrids were discovered to be promising leads molecules for constructing future compounds that have anti-diabetic properties. It is expected that these molecules can be used as antidiabetic drugs after their molecular investigation.

\section{ACKNOWLEDGEMENT}

The authors are thankful to the management and Principal of Modern College of Pharmacy for providing infrastructure and other research facilities.

\section{CONFLICT OF INTEREST}

The authors state that the publishing of this paper does not include any conflicts of interest.

\section{ABBREVIATIONS}

T2D: Type 2 diabetes; DM: Diabetes mellitus; HFD: High-fat diet; STZ: Streptozotocin; FT-IR: Fouriertransform infrared spectroscopy; TMS: Tetramethylsilane; ${ }^{1} \mathbf{H N M R}$ : Proton nuclear magnetic resonance; ${ }^{13}$ C NMR: Carbon-13 nuclear magnetic resonance; MHz: Megahertz; $\mathbf{C D C l}_{3}$ : Deuterochloroform; MS: Mass spectroscopy; CMC: Carboxymethylcellulose; Rf: Retention factor.

\section{REFERENCES}

1. Boland BB, Rhodes CJ, Grimsby JS. The dynamic plasticity of insulin production in $\beta$-cells. Mol Metab. 2017;6(9):958-73. doi: 10.1016/j. molmet.2017.04.010, PMID 28951821.

2. Ramachandran S, Rajasekaran A, Adhirajan N. In vivo and in vitro antidiabetic activity of Terminalia paniculata bark: an evaluation of possible phytoconstituents and mechanisms for blood glucose control in diabetes. ISRN Pharmacol. 2013;2013:(Article ID 484675). doi: 10.1155/2013/484675, PMID 23936668.

3. Sola D, Rossi L, Schianca GP, Maffioli P, Bigliocca M, Mella R, Corlianò F, Fra GP, Bartoli E, Derosa G. Sulfonylureas and their use in clinical practice. Arch Med Sci. 2015;11(4):840-8. doi: 10.5114/aoms.2015.53304, PMID 26322096.

4. Mohammed Iqbal AKM, Khan AY, Kalashetti MB, Belavagi NS, Gong YD, Khazi IAM. Synthesis, hypoglycemic and hypolipidemic activities of novel thiazolidinedione derivatives containing thiazole/triazole/oxadiazole ring. Eur J Med Chem. 2012;53:308-15. doi: 10.1016/j.ejmech.2012.04.015, PMID 22575535.

5. McCoull W, Addie MS, Birch AM, Birtles S, Buckett LK, Butlin RJ, Bowker SS, Boyd S, Chapman S, Davies RD, Donald CS, Green CP, Jenner C, Kemmitt PD, Leach AG, Moody GC, Gutierrez PM, Newcombe NJ, Nowak T, Packer MJ, Plowright AT, Revill J, Schofield P, Sheldon C, Stokes S, Turnbull AV, Wang SJ, Whalley DP, Wood JM. Identification, optimisation and in vivo evaluation of oxadiazole DGAT-1 inhibitors for the treatment of obesity and diabetes. Bioorg Med Chem Lett. 2012;22(12):3873-8. doi: 10.1016/j.bmcl.2012.04.117, PMID 22608962.

6. Kikkeri NM, Chikkur BPK. Synthesis and antioxidant activity of 2-amino-5methyl thiazol containing 1,3,4- oxadiazole-2-thiol moiety. Eur J Med Chem. 2013:1-8.

7. American Diabetes Association. Diabetes Care. Diagnosis and classification of diabetes mellitus. 2014 Jan;37;Suppl 1:S81-90. doi: 10.2337/dc14-S081, PMID 24357215.

8. Nayak Y, Hilleman V, Daroji VK, Jayashree BS, Unnikrishnan MK. Anti-diabetic activity of benzopyrone analogs in nicotinamide streptozotocin-induced type 2 diabetes in rats. Scient. World J. 2014:1-12.

9. Jarald EE, Joshi SB, Jain DC, Edwin S. Biochemical evaluation of the hypoglycemic effects of extract and fraction of Cassia fistula Linn. in Alloxan-induced Diabetic Rats. Indian J Pharm Sci. 2013;75(4):427-34. doi: 10.4103/0250-474X.119823, PMID 24302797.

10. Luzi L, Pozza G. Glibenclamide: an old drug with a novel mechanism of action? Acta Diabetol. 1997;34(4):239-44. doi: 10.1007/s005920050081, PMID 9451465.

11. Gopalakrishnan V, Iyyam Pillai S, Subramanian SP. Synthesis, Spectral Characterization, and Biochemical Evaluation of Antidiabetic Properties of a New Zinc-Diosmin Complex Studied in High Fat Diet Fed-Low Dose Streptozotocin Induced Experimental Type 2 Diabetes in Rats. Biochem Res Int. 2015;2015:350829. doi: 10.1155/2015/350829, PMID 26783461. 
12. Niu $\mathrm{P}$, Kang J, Tian $\mathrm{X}$, Song L, Liu H, Wu J, Yu W, Chang J. Synthesis of 2-amino-1,3,4-oxadiazoles and 2-amino-1,3,4-thiadiazoles via sequential condensation and I 2 -Mediated oxidative C-O/C-S bond formation. J Org Chem. 2015;80(2):1018-24. doi: 10.1021/jo502518c, PMID 25506709.

13. Sharma R, Soman SS. Design and synthesis of sulfonamide derivatives of pyrrolidine and piperidine as anti-diabetic agents. Eur J Med Chem. 2015;90:342-50. doi: 10.1016/j.ejmech.2014.11.041. PMID 25437620.
14

Jain AK, Gupta A, Bohra R, Lorenz I, Mayer P. Synthesis and structural elucidation of some novel aluminium(III) complexes with Schiff bases: crystal and molecular structure of $[\mathrm{Al}\{\mathrm{O}(\mathrm{C} 6 \mathrm{H} 4) \mathrm{CHNC} 6 \mathrm{H} 5\} 2\{\mathrm{HO}(\mathrm{C} 6 \mathrm{H} 4) \mathrm{CHNC} 6 \mathrm{H} 5\} 2]$ Br. Polyhedron. 2006;25(3):654-62. doi: 10.1016/j.poly.2005.07.028.

15. Sharma NB, Singh A. Synthesis and spectroscopic characterization of fivecoordinate aluminum complexes. J Indian Chem Soc. 2006;83:658-62.

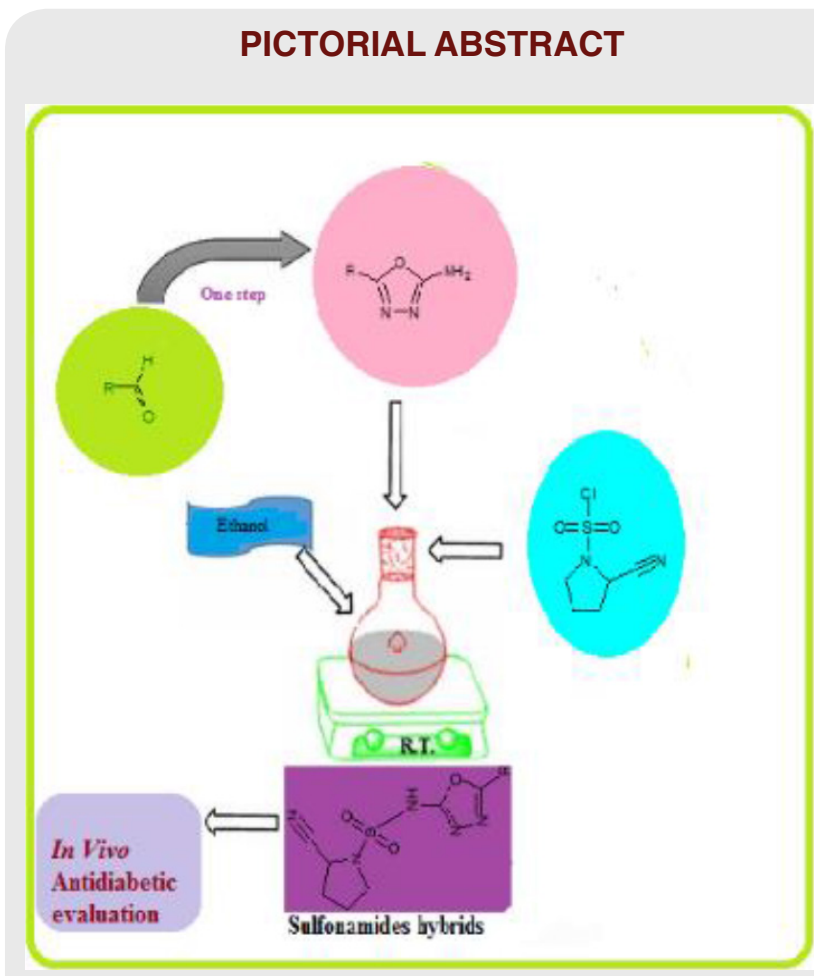

\section{SUMMARY}

It is estimated that approximately 463 million adults (20-79 years) have diabetes; by 2045, this number will reach 700 million. The amount of issues was proportional to the number of coexisting medication. Hypoglycemia, gastrointestinal problems and weight gain were the most common adverse events. In this research, sulfonamides are prepared as a reaction of sulfonyl chlorides with a 5-substituted 1,3,4-oxadiazole in ethanol as a solvent. The final synthesized compounds were evaluated for their hypoglycemic effects. Few compounds showed good antidiabetic activity compared to the standard drug Vildagliptin.

Cite this article: Salve MT, Jadhav Sr SB. Synthesis, Characterization and Antidiabetic Evaluation of Sulfonamide in Corporated with 1,3,4-Oxadiazole Derivatives. Indian J of Pharmaceutical Education and Research. $2021 ; 55(4): 1145-50$. 